\title{
What's in a ZPD? A case study of a young ESL student and teacher interacting through dialogue journals
}

\author{
Hossein Nassaji and Alister Cumming \\ Modern Language Centre \\ Ontario Institute for Studies in Education/University of Toronto
}

\begin{abstract}
Author contact: Alister Cumming, Modern Language Centre, OISE/UT, 252
Bloor Street West, $10^{\text {th }}$ floor, Toronto, Ontario, Canada M5S 1V6. Internet:

acumming@oise.utoronto.ca Phone: 416-923-6641, ext. 2538. Fax: 416-926-

4769
\end{abstract}

Authors' note: We thank Jim Lantolf, Joy Peyton, Merrill Swain, Gordon Wells, and two anonymous reviewers for helpful comments on initial drafts of this paper.

Total word count: 8,199 words 
Abstract: Aiming to provide a case-study account of features of the ZPD (zone of proximal development) in language teaching and learning, we analysed 95 exchanges in interactive dialogue journals written over 10 months between a 6year-old Farsi speaker beginning to learn English and his Canadian teacher. Using a scheme of language functions developed by Shuy (1993), we show how the teacher and student constructed and sustained a long-term written conversation involving intricate patterns of complementary, asymmetrical scaffolding. We interpret the findings to suggest the value of analysing language learning and teaching as integrally unified, interactive phenomena. We suggest questions worthy of future research into features of the ZPD in language teaching and learning. 
What does a ZPD (zone of proximal development) look like? How might we recognize one is being constructed? How do we know whether it is happening, or not? Answers to these questions are fundamental to guide--indeed, should form a rationale for--the practices of language teaching and learning. Moreover, they are necessary to substantiate and make relevant to education arguments for the centrality of sociocultural theory to language learning (e.g., Frawley, 1997; Lantolf, in press; Lantolf \& Pavlenko, 1995; Lave \& Wenger, 1991; Wertsch, 1991; Wells, in press). Our impetus for the present article was the impression that, despite a growing number of publications over the past decade advocating that language teaching and learning be conceptualized as sociocultural activity, following Vygotsky’s (1978) seminal definition of the ZPD, very few publications have documented precisely what the ZPD is, particularly how it is constructed in language instruction (but see, e.g., Adair-Hauck \& Donato, 1994; Aljaafreh \& Lantolf, 1994).

As a consequence, the notion of the ZPD remains something of a mysterious, idealized entity, often claimed to be in place by those promoting their particular approaches to instruction, but seldom systematically accounted for or critically evaluated. Without credible depictions of the ZPD that are germane to the ongoing practices of language education, key features of the ZPD may be ignored or distorted, as Dunn and Lantolf (1998) have argued at length in distinguishing Vgytosky's idea of the ZPD from Krashen's conceptualization of $i$ +1 .

Emphasizing this point, Mitchell and Myles (1998) have recently 
highlighted the uniqueness of sociocultural theory in contrast to other predominant conceptualizations of second language learning that have "concentrated mainly on modelling the development of language within the individual learner, in response to an environment defined fairly narrowly as a source of linguistic information" (p. 163). In particular, psycholinguisticallyoriented theories such as Universal Grammar (e.g., reviewed in Gass \& Selinker, 1994; Sharwood-Smith, 1994) or information-processing models (e.g., McLaughlin, 1990; MacWhinney 1997) have focussed on innate abilities or cognitive mechanisms that may facilitate or constrain people's learning of specific morpho-syntactic or lexical features in a second language. Alternatively, sociolinguistically-oriented theories have traced how the language varieties that adults develop in a second language arise from pragmatic functions people try to fulfill while communicating (e.g., Klein, 1998; Perdue, 1993) or vary according to contextual factors in people's social environments (e.g., Ellis, 1994, pp. 119-158; Preston, 1996; Tarone, 1988). Recognizing the need to combine psycholinguistic and sociolinguistic perspectives in ways that are relevant to education, some pedagogically-oriented theorists have focussed on documenting types of discourse interactions with or among learners that may facilitate their comprehension of meaning in a second language and potentially foster their learning of the language (e.g., Long, 1983, 1996), whereas others have aimed more broadly to account for 
the long-term antecedent and process variables in classroom behaviours that may explain achievements in language learning (e.g., Carroll, 1975; Chaudron, 1988).

Although increased understanding of such issues is surely valuable, they do not address directly the interactive nature of teaching and learning, so are of limited guidance in understanding such processes precisely. In contrast, Vygotskian theory claims to stand apart from, but also to unify, these alternative viewpoints by providing a psycholinguistic explanation of the sociocultural circumstances and processes through which pedagogy can foster learning that leads to language development. At the heart of the sociocultural perspective is defining the dialogic nature of teaching and learning processes within the ZPD as well as designing research that exemplifies its nature.

Vygotsky (1978: 86) defined the ZPD as "the distance between a child's actual developmental level as determined by independent problem solving and the level of potential development as determined through problem solving under guidance or in collaboration with more capable peers." Wells (1998: 345; in press) has summarized how recent analyses extend the notion of the ZPD beyond simply an "attribute of the learner" or something of "relatively fixed dimensions" to conceptualize the ZPD as "task-specific, reciprocal, and open-ended" and thus essentially "emergent", depending on the "manner in which the interaction unfolds as much as on the developmental stage reached by the participants." 
Importantly, as Dunn and Lantolf (1998: 420) have emphasized, Vygotsky claimed that learning is formed through the ZPD, which creates "a dialectic unity of learning-and-development", rather than students' stages of development setting a precondition (i.e., of "readiness") for their learning (as in Piaget's theories): In Vygotsky’s theory, language acquisition "provides the paradigm case" of learning leading development, because in this activity the "aspirant speaker must 'borrow' the knowledge and consciousness of the tutor to enter a language" (Bruner, 1986, p. 78) through the fundamentally human process of meaning making in collaborative activity with other members of the culture (Newman \& Holzman, 1993, p. 87). (Dunn \& Lantolf, 1998: 420)

Newman, Griffin and Cole (1989: 61) further emphasized the importance of the ZPD in linking the social discourse of teachers and learners with the cognitive dimensions of students' learning:

The concept of ZPD was developed within a theory that assumes that higher, distinctly human, psychological functions have sociocultural origins. The activities that constitute a zone are the social origins referred to; when cognitive change occurs not only what is carried out among participants, but how they carry it out appears again as an independent psychological function that can be attributed to the novice. That is, the 
culturally mediated interaction among people in the zone is internalized, becoming a new function of the individual. Another way to say it is that the interpsychological becomes also intrapsychological.

Building on these concepts, Frawley (1997: 102) has stipulated two criteria for demarcating the "finer structure of the ZPD" that are particularly relevant to the present study and to other situations where a teacher leads a student on to enhanced abilities. Frawley observed that the ZPD:

...must be intersubjective but asymmetric. As to the former, an individual must engage in joint attention with at least one other; by discounting their differences and thereby functionally deriving a shared definition of situation, they have intersubjectivity and prospects for on-line growth. As to the latter, one person must be more capable in the task and so lead the other beyond the actual level of growth. What is important is that both intersubjectivity and asymmetry can be constructed and maintained by language.

Frawley alludes to the concept of scaffolding, generally understood in cognitive psychology as progressive help provided by the more knowledgeable to the less knowledgeable (e.g., Wood, Bruner \& Ross, 1976). But numerous authors have recently observed that peer groups of students or work teams, for instance, are also able to construct a ZPD through joint efforts among their members, 
without expertise residing in any one member of the group (Forman, Minick \& Stone, 1993; Newman \& Holzman, 1993; Swain, 1997; Wells, in press).

\section{The Present Study}

In applying these notions to second-language education, many authors have highlighted the centrality of ongoing verbal collaboration between a novice learner and an expert guide, such as a teacher or more proficient peers, in specific kinds of learning tasks (Adair-Hauck \& Donato, 1994; Lantolf \& Appel, 1994; Lantolf \& Pavlenko, 1995; McCafferty, 1994; McDonell, 1992; Swain, 1997). For this reason, we decided, in order to study the ZPD in detail, to look to dialogue journal writing--a situation where language teaching and learning are organized so that communication is systematically dialogic. In addition, these communications are documented naturally, as long-term, purposeful exchanges of written texts between a student and teacher, providing data that are relatively straightforward to gather and analyse. A body of research has already emerged on dialogue journals in language teaching and learning (e.g., Peyton \& Staton, 1993; Staton, Shuy, Peyton \& Reed, 1988; see also Allison, 1998), on whose basic descriptions we were able to build the present analyses. For example, Peyton (1993a) and Shuy (1993) have traced how ongoing dialogue journal communications progressively prompted a teacher and her diverse group of students learning English to use 
writing interactively, meaningfully, and appropriately with one another, assisting each student in unique ways, for example, to establish friendship with the teacher, to provide a medium for asking for new knowledge, and to think out and find solutions to problems. Peyton (1993b) studied how a teacher's questions in dialogue journals promoted her students' communications, uses of new language forms, and thinking.

Little of the previous inquiry into dialogue journals with second language learners, however, despite its taking a functional approach to the analyses of communication, has adopted an explicitly Vygotskyan theoretical framework (though Peyton, 1990; Staton, Shuy, Peyton \& Reed, 1988 move in this direction). Likewise, previous research about the ZPD in second-language education has mostly focussed on spoken, rather than written, interactions (e.g., articles in Lantolf \& Appel, 1994). Where such research has dealt with writing, it has addressed pedagogical circumstances--such as teachers' corrections of (e.g., Aljaafreh \& Lantolf, 1994; Nassaji \& Swain, in press) or peer feedback on (e.g., Villamil \& de Guerrero, 1996) students' writing--that differ substantively from the ongoing communications between students and teachers that appear in dialogue journals. As Wells (1990) pointed out, most inquiry on students' writing has considered composition as a fundamentally monologic, solitary activity, and thus has overlooked its interactive qualities, which may be especially important at 
the early stages of learning literacy. Moreover, as Ferris, Pezone, Tade \& Tinti (1997) observed, nearly all prior research on interactions in writing between language teachers and students has been limited to teacher's unidirectional comments or isolated feedback provided at one particular moment in time, rather than as continual interactions over time.

We approached the present study with the purpose of analysing the written interactions between one ESL student and his teacher in the context of their dialogue journals, hoping to elucidate some of the salient qualities of the ZPD that they mutually constructed in this context over time. We have focussed exclusively on their dialogue journal texts, in the interests of clarifying features of the ZPD that appeared there, though we recognize that this research might usefully have also investigated (but also been complicated by the many interdependent aspects of) the broader social context of their classroom, for example, in the ethnographic manner pursued by Dyson (1993) or Peyton (1990) or through the kinds of classroom experiments devised by Newman, Griffin and Cole (1989).

\section{Context}

We collected 95 continuous, interactive dialogue journal exchanges written over 10 months by a student we call "Ali", and responded to by his teacher, who we call "Ellen" (both are pseudonyms). When he started producing 
these dialogue journals, Ali was 6 and had just moved to Canada from Iran. The journals were his first written productions in English, though he had previously written some Farsi in Iran. Ellen, an experienced teacher, used (by her own account) a whole language approach to instruction--actively involving her students in frequent and diverse uses of oral and literate communications based on their own experiences and interests (cf. Edelsky, 1986; Milz, 1985; Peyton, 1990; Urzua, 1987). Ellen taught a split class of grades 1 and 2 at a public school in a multi-ethnic part of downtown Toronto.

The journals spanned the latter half of Ali's grade 1 year and the first three-quarters of his grade 2 year in Ellen's classroom. The journals were written every few days as part of routine classroom activities, forming a continuous flow of exchanges in single notebooks (comprising 4 notebooks in total), conforming to Peyton's $(1990 ; 199)$ definition: “A dialogue journal is a written, ongoing interaction between individual students and their teacher in a bound notebook". Ellen used journal writing because she believed it provides a useful context for students to share their ideas and a helpful tool for their developing literacy through meaningful communications. All the journals were written prior to either Ali or Ellen being aware of our research purposes, so they represent naturalistic classroom data. As a general strategy, Ellen told students to initiate topics in the 
journals based on their personal interests and choices. Ali focussed his journals on a variety of concerns in his daily life at home and in school. Each exchange in the dialogue journals consisted of either two turns (i.e., Ali’s initiation--Ellen's response), or three turns (i.e., Ali's initiation-Ellen's response-Ali's follow-up). To highlight their interactive nature, and because Ellen responded to nearly every initial journal entry that Ali produced, we have treated them as exchanges (i.e., both Ali and Ellen wrote to each other 95 times), rather than counting each entry from each person separately. Ellen's written responses were mostly brief, comparable in length to those of the first grade teacher that Peyton (1990) studied but considerably shorter than has been documented for teachers responding to journals of older students (e.g., Staton, Shuy, Peyton, \& Reed's 1988 studies of a grade 6 teacher). Two (verbatim) samples of these journals showing two-turn and three-turn interactions are:

1. (week 1)

Ali: Today is Friday. May $199515^{\text {th }}$. Today is +12 A.M. Yestoday is Mather's Day. I lave oranges. Today is cold Day. I Lave floweR. I liak My MaM. I Lak apple and bonani. My borsday is May 1995 22. I Lak Mrs. [Ellen]. I am 7 yorz old. I liak Layen keng. Yestoday is vary cold Day.

Ellen: I love flowers too!

2. (week 12)

Ali: Today is Thursday Nov. 16th 1995. the temperature is -0 A.M. 
today is a sunny Day. I wach Mighty Morphen power rengers

Ellen: What time are they on T.V.?

Ali: 4:30 on Fox 29

\section{Analyses}

We analysed the written texts of the dialogue journals using a scheme of 14 language functions developed by Shuy (1993) for his study of dialogue journal interactions in an ESL teaching context:

1. Reporting personal facts

2. Reporting general facts

3. Reporting opinions

4. Requesting personal information

5. Requesting academic information

6. Requesting general information

7. Requesting opinions

8. Requesting clarification

9. Thanking

10. Evaluating

11. Predicting

12. Complaining

13. Apologizing

14. Giving directives

Only 11 of these functions were useful as a means of classifying the data, however. Neither Ali nor Ellen displayed in the journals any instances of "requesting academic information" or "complaining"; and "thanking" occurred so infrequently, and embedded within other language functions, as to not warrant 
our analysing it as a separate language function.

We first read and made a profile of all the dialogue entries then segmented the texts into T-units (following Hunt's 1970 definition of a T-unit as a clause with its subordinate elements). We next categorized these into the 11 language functions then tabulated and analysed them in various exploratory ways, seeking to identify patterns in the data overall. In total, we identified 703 T-units (566 for Ali and 137 for Ellen). Our inter-coder agreement on a sample of $20 \%$ of the data, selected from every 5 th journal entry (101 T-units over 19 exchanges), was 100\% (i.e., full agreement) for the segmentation of the data into T-units and $92 \%$ for the coding of the language functions. The few discrepancies in coding were resolved through discussion, then one of us (Nassaji) segmented and coded the remaining T-units.

After initially tabulating the frequencies of each of the 11 language functions (reported below), we decided to group the data in two ways, reducing the data further so as to discern more clearly any patterns in them. First, we clustered the 95 exchanges in the dialogue journals into groups based on weekly periods (i.e., entries written Monday to Friday). This yielded 23 clusters of exchanges written over 23 different but continuous weeks (except for the school's summer break). Second, we combined certain of the language functions on the basis of logical similarity (i.e., by combining all "requesting" functions together 
and all "reporting" functions together, both of which formed the majority of language functions appearing in the data) as well as frequency (i.e., by excluding "directives" and "apologies", which appeared infrequently in the data).

\section{Findings}

Our findings can be summarized as demonstrating two salient characteristics of the ZPD in this dialogue journal writing context: (a) sustained intersubjectivity and (b) complementary, asymmetric scaffolding. The duration of our data span a much longer period of verbal interaction between a teacher and learner than is typically available from other studies, particularly at the early stages of language learning; and its analyses clarify trends in these interactions that would probably not be possible to perceive in the ordinary activities of educational practice (though they may well be an implicit aspect of Ellen's practical, professional knowledge). We make no claims to be refining theoretical conceptualizations of the $\mathrm{ZPD}$, or even to have assessed the overall quality of the ZPD that we document (for example in contrast to other possible teachinglearning configurations or experiences, or its impact on learning). Rather, our purpose is to document and interpret how the ZPD may have been formed, in this one sample instance, over a longitudinal perspective, so that language educators may be able to perceive, utilize, and evaluate the concept of the ZPD further. 
Most basically, Ali and Ellen communicated routinely over nearly a year with each other through written English using a variety of language functions and forms to express themselves and to interpret each other. As the sample extracts from the dialogue journals quoted below demonstrate, both Ali and Ellen used these written interactions as a focussed context to communicate in English, attempting to understand and appreciate each other. We assume this established a basis for mutual understanding through the "tool" of language, on which a ZPD could develop, though this had to be constructed progressively (as Wertsch, 1991, has demonstrated, and as we try to see below).

\section{Frequencies}

As Figure 1 displays, these written communications encompassed a variety and range of language functions. Figure 1 presents the frequency of the 11 language functions we coded as percentages of the total T-units in the dialogue journals. 


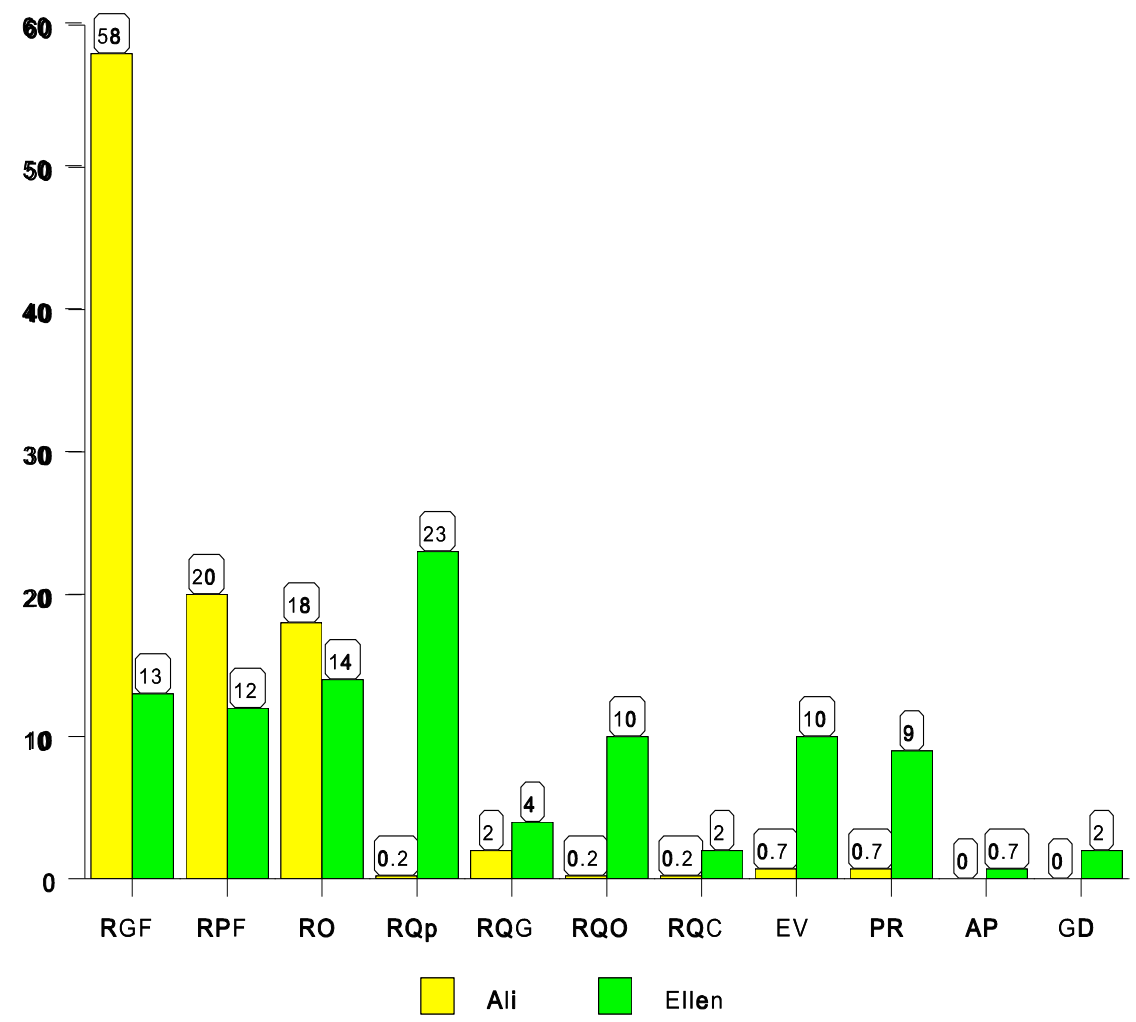

Figure 1

As Figure 1 makes evident, there was a fundamental asymmetry to the distribution of these language functions between Ali and Ellen. Ali's most frequent language functions were "reporting" either general facts, personal facts, or opinions (totalling 96\% of his T-units). Ellen produced many "reporting" functions too (39\% of her total T-units), but she also produced just as many language functions "requesting" either personal information, general information, opinions, or clarifications (totalling 39\% of her T-units). Ellen also performed other functions such as "evaluation" (10\% of her T-units), "predicting" ( $9 \%$ of her T-units), and "giving directives" ( $2 \%$ of her T-units), which Ali did only rarely, if at all, in this context.

But the variety and value of Ellen's language functions have to be recognized, not simply as proportional frequencies, but for the ways in which she pitched her discourse to match Ali's basic "reporting" mode. We assume Ellen 
was striving to scaffold their written interactions to prompt Ali's potential for learning English in this context. Through scaffolding, the quintessential Vygotskian act of pedagogy, a teacher as a "knowledgeable participant creates, by means of speech, supportive conditions in which the novice can participate, and extend different skills and knowledge to higher levels of competence" (Donato, 1994; 40). We suggest that Ellen, having established a basis for literate intersubjectivity in the journal context, subtly modelled the discourse to prompt Ali's fuller, more extensive engagement in the written communications while also challenging Ali to shape them, through enhanced language functions, in new directions (in a manner akin to that described by Peyton 1993b for a different teacher's role in dialogue journals). In turn, we observe that Ali also regulated Ellen's discourse production in the dialectic manner characteristic of the ZPD. Certain patterns in Ellen's and Ali's functional exchanges characterized their interactions. We think five of these patterns display salient aspects of their mutual process of constructing a ZPD: their patterns (a) of questioning, (b) of give and take in the interactions, (c) of reporting and requesting, (d) of Ellen's evaluations, and (e) of Ali's appropriation of spoken language into the written genre. In what follows, we present excerpts from the dialogue journals that show these patterns. 


\section{Questioning}

First, Ellen's written questions and Ali's responses to, and adoptions of, them showed certain patterns. In the early weeks of the journals, Ellen posed simple, routine questions seemingly to engage Ali in the discourse and to show Ali how to interact, for example:

3. (week 1)

Ali: Today is Thorssday. Yestoday is +13 P.M. May 1995 is $11^{\text {th }}$. Tomorro is +11 A.m. I liak Bunane. And appil.

Ellen: Do you like oranges?

Ali: Yes

4. (week 2)

Ali: Today is +14 A.M. May 1995 is 23th. Yestoday is my borday. I am 7 Yors old. I love my Mom and my Dad. Today is Teusday. I love my Teacher. I love Appl TREE Ellen: Did you have a birthday cake?

Ali: Yes

As their exchanges progressed, Ellen converted her simple yes/no questions into queries for deeper, more substantial information. At the same time, she modelled (either implicitly or explicitly) the spelling and syntax of phrases Ali was trying to express. For example:

5. (week 12) 
Ali: Today is Friday. November the $17^{\text {th }}$ 1995. The Temperature is +1A.M. Today is A sunny Day. I Love Anem and I cood till you whach!LionTaGer-chik-Gold Fish-That is what I Like.

Ellen: Why do you like tigers, chicks and goldfish?

6. (week 20)

Ali: Today is wedensday Jan. The $24^{\text {th }}$ 1996. The temperature is +5 A.M. It is a cold day. I like power ranger and thir sords. But I Don't wach the move of it. It can drow the redranger.

Ellen: How do you know to draw the Power Rangers?

Ali: From a book

Ali gradually picked up these questioning patterns himself, using them as

a basis to engage Ellen in the written dialogues and to inquire about issues that

interested him. For example:

7. (week 15)

Ali: Today is Thursday. Dec. $7^{\text {th }}$ 1995. The temperature is -5A.M. today is a sunny Day. I LikD That NiGht. DiD we have that again? I hope we have that again.

Ellen: Yes, we will have another Concert Night! Are you going to come again?

Ali: Yes, I do come again.

8. (week 23)

Ali: Today is Monday Feb. The $5^{\text {th }}$ 1996. The temperature is $-14^{\text {th }} \mathrm{C}$. It is a cold day. I can't even see the moon becas My window was frosen. do the moon come out in spring?

Ellen: Oh, yes the moon comes out in spring, in summer, in fall, and of 
course, in winter!

Over time, Ellen gradually decreased the proportion of her questioning functions: Of her overall use of questions, 39\% appear in the first third of the data, $33 \%$ in the second third, then $27 \%$ in the final third. Correspondingly Ali increased his: Of his overall use of questions, $26 \%$ were in the first third of the data, $33 \%$ in the second third, then $40 \%$ in the final third.

\section{Give and Take}

Second, this asymmetry of language functions followed a pattern of "give and take" in terms of frequency. At times, when Ali increased the frequency of language functions he used, Ellen correspondingly decreased hers, seemingly to allow Ali greater "voice". For instance Example 9 shows Ali writing an unusually long entry containing 16 language functions, to which Ellen responded with an unusually brief entry of only one language function. Similarly, in Example 10, when Ali wrote a fairly long entry including 12 language functions, Ellen replied with just one evaluative function.

9. (week 3)

Ali: Today is Mounday.June $19955^{\text {th }}$. Yestoday is god Day. YesToday I aM going To park. Today is teperature is +19 A.M. I love grass. I Love park. I Love My scool. I Love My Teacher. I am seven Yors old. I love you Mr. [Ellen]. I Love baby dish and tadpole. I love my clas RooM. Do You 
laik Me. I love frog. I Love sole dog. I love my mom and my Dad

Ellen: Yes, I like you Ali

Ali: Tanks

10. (Week 14)

Ali: Today is Friday.Dec.1rst 1995. the temperature is +6 A.M. Today is a hot day. at November the 28th was my brother birthday. My MomMake hime cake and took hime to his school. his techer give hime a prasent. My Mom said I am 8 yers old and My sister is 7 yers old and My brother is 6 yers old. why we cant walkon the Grass at resses. we most walk arund the school.

Ellen: Ali, you do excellent work

Ali: Tank you

Conversely, every few weeks Ellen increased her frequency of language functions, possibly to prompt Ali to increase his. In many cases when Ali wrote shorter journals with fewer language functions, Ellen tended to produce comparatively lengthier responses and more language functions. For instance in Example 11, Ali's 5 language functions (much shorter than his entries in the previous week) prompted Ellen to provide a response of 6 language functions. Similarly, in Example 12, when Ali produced an entry of just 4 language functions, Ellen tried to engage him to write more about his feelings.

11. (Week 10) 
Ali: Today is thursday.Nov.the 2nd 1995. The temperature is +15 A.M. today is a raning Day. halloween is ower. I Go checo or churet last Night. and I saw tish and Mayer and bingemeh. the End.

Ellen: What did you get for Trick-or-Treat? What was your costume? Dear [Ali], I'm glad you listened to and obeyed your mother at 12:00, she is trying to help you learn. We will see you tomorrow with a big smile! From Mrs [Ellen]

Ali: Notheng

12. (Week 17)

Ali: Today is Tuesday.Dec.19th 1995. The Temperature is 11A.M. It is a Cold Day. I very very miss kathryn.

Ellen: Kathryn was a very kind student. We will all miss her very much. Do you think she will miss us?

Ali: yes

These periods sometimes alternated with other periods when the two people matched their frequency of language functions together, establishing common points of equilibrium in their communications, or what Shuy (1993: 148151) called a "language function threshold". Ellen's backing off, possibly to allow Ali greater expression, seems an important element of the ZPD, permitting the scaffolding to be contingent and thereby to sustain the potential for their mutual intersubjectivity (Aljaafreh \& Lantolf, 1994).

We established an index of the "complementarity" (Shuy, 1993: 137) of 
Ellen's and Ali's interactions by counting the number of the 11 unique language functions that both Ali and Ellen used over the 23 week period. The more Ali used more different kinds of language functions, the more Ellen did. Ellen pitched her use of different language functions, for the first 10 weeks, just above the number that Ali used, then from week 10 on she pitched them just below the number Ali used. For example, in the initial week of the journal exchanges, Ali used 3 kinds of language functions ("reporting general facts", "reporting personal facts", and "reporting opinions"), to which Ellen responded with 2 of the same language functions. By week 7, when Ali had increased his uses of language functions to 5 different kinds, Ellen correspondingly increased her language functions to 4 different kinds.

\section{Reporting and Requesting}

Third, this ongoing asymmetry became evident when we analysed and consider the two language functions most frequently used by Ali and Ellen: reporting and requesting. Ellen was, over most of the period of the journal writing, radically modulating the frequency of her "requests", seemingly to ascertain how best to pitch them to Ali (though, by the final weeks of the journal exchanges, the two had reached a relatively harmonious balance in terms of their communicating through these types of language functions). Overall, in only $6 \%$ of 
the instances when Ali produced a report of general facts did Ellen, in her replies, request general information from him. Instead, in the other $94 \%$ of the journal entries Ellen responded to Ali's reporting of general facts with a different language function, such as requesting clarification (Example 13) or requesting personal information (Example 14). We might surmise that in these exchanges Ellen was attempting to steer Ali away from this most frequent of his language functions, i.e., simply "reporting", though this pattern may simply reflect the "natural" flow of adjacency pairs in conversation typical of student-teacher interaction.

13. (Week 3)

Ali: Today is friday.May 26th 1995. [Reporting general facts] Today is sunny Day. Today is +14 A.M. [Reporting general facts] [pictures of tadpoles]

Ellen: How many tadpoles are there?

[Referring to the picture]. [Requesting clarification]

Ali: 12 tadpoles [Giving clarification]

14. (Week 8)

Ali: Today is Tusday Oct 17th $1995 . \quad$ [Reporting general facts]

The temperature is +4 A.M.

[Reporting general facts]

today is sunny and cold Day.

[Reporting general gacts]

Ellen: Did Jack frost come to your house last night?

[Requesting personal info]

Ali: No

[Reporting personal info] 
Particularly revealing, however, was the pattern when we isolated the relationship between Ali’s reporting of opinions and Ellen's requesting of opinions (perhaps the highest level of interpyschological functioning aspired to in the journal exchanges). The more Ali reported opinions, the less Ellen asked for opinions. This relationship was most noticeable in weeks 1 to 6, when Ellen frequently solicited Ali's opinions with phrases such as "Do you like red balloons?" as Ali was scarcely providing personal opinions on his own. As the journals progressed, Ali came to produce more opinions and Ellen gradually refrained from requesting them (except in Week 19).

\section{Evaluations}

A fourth pattern of complementary asymmetry appeared in Ellen's uses of evaluation functions. As Ali produced more language functions in total, Ellen provided more evaluative functions, mostly as praise to Ali for his accomplished output, as in Example 10 above and Example 15 below. But she seemingly held off on producing evaluative remarks when Ali's written production decreased in the following journal entry. Ellen's evaluations peaked, along with Ali's language functions, at weeks $3,5,11$, and 19 , but they trailed off in the weeks immediately following these peaks, when Ali's total written output declined. 
15. (week 3)

Ali: Today is manday. May $199529^{\text {th }}$. Today is +17 A.M.Today is hoT Day. I love My scool. My school is very bag. My school is god school. I Love tapole.

Ellen: Great

\section{Appropriating Spoken into Written Forms}

A final observation concerns the instances when Ali's and Ellen's two-part exchange structure extended into three-part exchanges. In some instances, both Ali and Ellen tried to extend, by posing questions to each other (to which the other then responded), their usual two part exchanges, seemingly to lengthen the discourse and sustain their intersubjectivity, as in Example 16:

16. (week 3)

Ali: May 1995 is $24^{\text {th }}$. Today is Wednesday. Today is cold day. What is the Temperatue?

Ellen: The temperature is 12. Do you like dinosaurs?

Ali: Yes.

Of particular theoretical significance, though, is that Ali often spontaneously added a third, closing response to the written interactions, forming the triadic structure of "request for information-answer-acknowledgement" common to classroom and conversational spoken discourse (Lemke, 1990). Out of 
the 95 exchanges in the journals, 47 (or about half) were triadic, that is, Ali ended the written interactions by a third move reacting to Ellen's comments or questions. In Example 17, taken from the first week of the journal exchanges, Ali spontaneously reacted with "me too" to Ellen's compliment. In Example 18, ten weeks later, Ali formed a triadic exchange by posing a question, seemingly to clarify Ellen's intentions or reference.

17. (week 1)

Ali: Today is Manday, May is 8th. The Yestoday is $6^{\text {th }}$. I lave Mrs.[Ellen] My frand shawN. May 1995. Today +6.

Ellen: Shawn and I love you, too, [Ali].

Ali: Me too.

18. (Week 11)

Ali: Today is Friday Nov. 10th 1995. the temperuture is +? A.M. Today is snow Day. Today I Go to Iranian school at 4 O'clok. alow the Friday My Iranian scool is on 4 O'clak.

Ellen: Do you like this day better?

Ali: What Day

The appearance within the written medium of the triadic structure characteristic of speech may signal that Ali was learning new mediational means from a variety of sources around him, such as classroom or conversational discourse, and developing his abilities by extending what is appropriate in one domain to 
another. But (as Jim Lantolf has suggested, in commenting on this interaction), it may be that Ellen's (or other teachers) later role in promoting Ali's literacy will eventually be "to purge" such intrusions of the oral onto the written genre (although our data do not show evidence of obvious moves toward more essayisttype literate texts among the journal exchanges).

\section{Implications}

We have presented this analysis as exemplifying some of the intricate patterns of written communication that a language teacher and a young, beginning ESL student mutually constructed as a ZPD. Using an analytic scheme that highlights the functional dimensions of interpersonal communication, we have shown various patterns in the written exchanges between the teacher and student that sustained--in a complementary, dynamic, and evolving manner over nearly a year-conditions for an ESL student's learning English literacy, scaffolded by his teacher. Although we have described these processes as characterizing the construction of one ZPD, our findings only offer partial answers to the question posed in the title of this article. But they raise issues of more general significance concerning the unity of language teaching and learning as well as research appropriate to understanding them.

This dialogue journal writing set a long-term context for the student and 
teacher to communicate routinely through written English. In the process, we have assumed that Ali came to appropriate aspects of English that he personally determined were worth expressing, while Ellen contributed to and edged him forward in this process, engaging with his written accomplishments and at the same time herself coming to understand better the student and his personal concerns and abilities. Both acted as proficient users of English-in spite of Ali's emergent spellings, vocabulary, syntax and penmanship--because the dialogue journals created a "setting for thought" (Butterworth, 1993) in which both participants reciprocally shared common knowledge, purposes, and tools of communication, evidently understanding and appreciating them. Instantiating this shared assumption as written English seemed to help Ali perform in his second language, while Ellen demonstrated an ongoing sensitivity to his doing that. What then characterized learning and teaching within this ZPD? The words of Newman, Griffin, and Cole (1988: 63-64) almost perfectly apply (though they originally described other situations of teaching and learning):

Our particular interest in education leads us to notice that the teacher reciprocally applies the process of appropriation in the instructional interactions. In constructing a ZPD for a particular task, the teacher incorporates children's actions into her own system of activity...Just as the children do not have to know the full cultural analysis of a tool to begin 
using it, the teacher does not have to have a complete analysis of the children's understanding of the situation to start using their actions in the larger system. The children's actions can function within two different understandings of the significance of the task: the child's and the teacher's. Both are constrained by sociohistorical understandings of the activity setting in which they are interacting. The fact that any action can always have more than one analysis makes cognitive change possible. Children can participate in an activity that is more complex than they can understand, producing "performance before competence", to use Cazden's (1981) phrase.

A sociocultural perspective highlights teaching and learning in conjunction and close-up, looking to fundamental characteristics of the ZPD as a set of interactive processes wherein learning occurs because teaching facilitates it. The focus of much other inquiry into second language education has isolated these elements from one another, fragmenting their essential interconnectedness and thereby attending to matters other than the ZPD: for example, by treating language as a system of elements divorced from their social functions and contexts (as in many structural linguistic descriptions), by considering students solely as individuals in terms of their acquisition of a language system (as in psycholinguistically-oriented research on second language acquisition that 
neglects societal or cultural variables), by observing teaching as separate acts of behaviour (as in teaching effectiveness research that does not account for variation in contexts or populations), or by formalizing assessment as a process to occur generally over whole educational systems or by specifying curricula as the organization of performance standards for students to attain alike (as in many current, government-mandated educational policies around the world).

In addition to imprecision about what actually occurs in the processes of teaching and learning, such a fragmented view of education may overlook or even obscure matters that are integral to language teaching and learning. For example, Cumming (1998) in reviewing recent research on second-language writing noted how it is compartmentalized into studies of either students' texts, composing processes, or social contexts, or it has treated key participants--such as teachers, students, or academic or other communities--as relatively separate, isolated entities. Though research into these specific aspects of second-language writing or educational roles helps to deepen understanding of their significance, the recent published literature conspicuously lacks studies and theoretical models (other than the ZPD) that can explain how teaching and learning occur in a way that preserves, rather than fragments, their integral linguistic, psychological, and sociohistorical dimensions in the contexts of real educational activities.

We hope that the present case study helps, if only in a small way, to 
counter this dilemma of fragmentation and divergent foci by presenting a unified account of the ongoing, reciprocal dimensions of language teaching and learning, highlighting certain processes of functional interaction that set conditions for learning through complementary written interactions. Nonetheless, it is obvious that the present study is limited to a single student and teacher, interacting in a single type of educational activity at the earliest stages of learning and teaching certain written functions of just one language. Moreover, we make many assumptions about what Ali may have learned in this context as well as what Ellen was trying (either implicitly or explicitly) to do. So our interpretations, though grounded in empirical data, are at most exploratory and paradigmatic rather than verified or representative. Moreover, our focus of analysis on language functions instantiated in syntax (i.e., t-units) begs the question of which units of analysis are appropriate to understanding the ZPD (cf. Zinchenko, 1985) and indeed which aspects of language, thought, or activity structure are integral to it, given that our data could be analysed in various other ways than we have presently attempted (based on Shuy's 1993 precedent).

Apart from the need to extend the present analyses to other pedagogical processes, contexts, and aspects of interaction and language, our case study raises several questions worthy of further inquiry to understand the ZPD in language teaching and learning: How can we know for certain when a ZPD is really being 
constructed, or indeed evaluate whether one was truly constructed in the present instances? (in terms of evidence to establish its parameters, processes, and effects, as well as that the intersubjectivity required to sustain it really exists?) What happens when a ZPD breaks down or subsides? (or might this have happened in the latter weeks of the dialogue journals, when Ellen and Ali reached a relatively stable pattern of functional interaction, or were they just communicating harmoniously by then with each other?) How do teachers and students themselves perceive their ZPD? (a question that we could have addressed, for example, by interviewing them about their written interactions.) How do contexts outside of the ZPD interact with it? (for instance to contribute to the ZPD, as in the example of Ali's appropriation of the triadic exchange structure of English conversation into his writing, or to constrain it, for example, in ways that our focus on just the student's and teacher's written texts may not have allowed us to perceive?) What distinguishes the craft of a skilled teacher in constructing a ZPD? (for example from other knowledgeable users of English, such as pen-pal peers who might have communicated with Ali through dialogue journals, or student teachers who may just be learning how to establish a ZPD?) How might we evaluate the quality of a ZPD? (for example to determine its effectiveness or limitations, or to know how to improve it?).

Many of these issues are worth addressing through further research that 
tries to highlight more precisely the reciprocal, contingent progression of teaching and learning, for instance, by gathering longitudinal data and ethnographic documentation on the local contexts of communication and education, by utilizing complementary methods (such as observation, text analyses, and interviewing) to probe deeply into specific circumstances, and by pursuing interpretive analyses of these. Some issues may benefit from comparative analyses across educational situations that differ marginally or radically on key, select variables. Contextually-grounded experiments that manipulate certain features of the teaching-learning process may also produce insights into some of these matters, providing they do not disrupt the spontaneous, delicate relationship between teachers and learners. 


\section{References}

Adair-Hauck, B. and Donato, R. 1994: Foreign language explanations within the zone of proximal development. Canadian Modern Language Review 50: $532-557$.

Aljaafreh, A. and Lantolf, J.P. 1994: Negative feedback as regulation and second language learning in the zone of proximal development. Modern Language Journal 78: 465-483.

Allison, D. 1998: Investigating learners' course diaries as explorations of language. Language Teaching Research 2: 24-47.

Bruner, J. 1986: Play, thought and language. Prospects 16: 77-83.

Butterworth, G. 1993: Context and cognition in models of cognitive growth. In Light, $\mathrm{P}$. and Butterworth, $\mathrm{G}$ editors, Context and cognition: Ways of learning and knowing, Hillsdale, NJ: Erlbaum, 1-13.

Carroll, J.B. 1975: The teaching of French as a foreign language in eight countries. New York: John Wiley.

Cazden, C. 1981: Performance before competence: Assistance to child discourse in the zone of proximal development. Quarterly Newsletter of the Laboratory of Comparative Human Cognition 3: 5-8.

Chaudron, C. 1988: Second language classrooms: Research on teaching and learning. New York: Cambridge University Press.

Cumming, A. 1998: Theoretical perspectives on writing. Annual Review of Applied Linguistics 18: 61-78.

Donato, R. 1994: Collective scaffolding in second language learning. In J. Lantolf and G. Appel, editors, Vygotskian approaches to second language research, Norwood, NJ: Ablex, 33-59.

Dunn, W. and Lantolf, J. 1998: Vygotsky's zone of proximal development and Krashen's $I+1$ : Incommensurable constructs; incommensurable theories. Language Learning 48: 411-442. 
Dyson, A. 1993: Social worlds of children learning to write in an urban primary school. New York: Teachers College Press.

Edelsky, C. 1986: Writing in a bilingual program, Norwood, NJ: Ablex.

Ellis, R. 1994: The study of second language acquisition. Oxford: Oxford University Press.

Ferris, D. R., Pezone, S., Tade, C. R., and Tinti, S. 1997: Teacher commentary on student writing: Descriptions and implications. Journal of Second Language Writing 6: 155-182.

Forman, E., Minick, N. and Stone, C., editors, 1993: Contexts for learning, New York: Oxford University Press.

Frawley, W. 1997: Vygotsky and cognitive science: Language and the unification of the social and computational mind. Cambridge, MA: Harvard University Press.

Gass, S. and Selinker, L. 1994: Second language acquisition: An introductory course. Hillsdale, NJ: Lawrence Erlbaum.

Hunt, K. W. 1970: Syntactic maturity in school children and adults. Chicago, IL: University of Chicago Press.

Klein, W. 1998: The contribution of second language acquisition research. Language Learning 48: 527-550.

Lantolf, J., editor (in press). Sociocultural theory and second language learning. Oxford: Oxford University Press

Lantolf, J. P. and Appel, G., editors, 1994: Vygotskian approaches to second language research. Norwood, NJ: Ablex.

Lantolf J. P. and Pavlenko, A. 1995: Sociocultural theory and second language acquisition. Annual Review of Applied Linguistics 15: 108-124.

Lave, J., and Wenger, E. 1991: Situated learning: Legitimate peripheral 
participation. New York: Cambridge University Press.

Lemke, J. L. 1990: Talking science: Language, learning, and values. Norwood, NJ: Albex.

Long, M. 1983: Native speaker/non native speaker conversation and the negotiation of comprehensible input. Applied Linguistics 4: 126-141.

Long, M. 1996: The role of the linguistic environment in second language acquisition. In Ritchie, W. and Bhatia, T., editors, Handbook of second language acquisition. San Diego: Academic Press, 413-468.

MacWhinney, B. 1997: Second language acquisition and the competition model. In de Groot, A. and Kroll, J. editors, Tutorials in bilingualism:

Psycholinguistic perspectives, Hillsdale, NJ: Lawrence Erlbaum, 113-144.

McCafferty, S. G. 1994: Adult second language learners' use of private speech: A review of studies. Modern Language Journal 78: 421-436.

McDonell, W. 1992: Language and cognitive development through cooperative group work. In Kessler, C., editor, Cooperative language learning: $A$ teacher's resource book, Englewood Cliffs, NJ: Prentice Hall Regents, 5154.

Milz, V. 1985: First graders' uses for writing. In Jagger A. and Smith-Burke, M., editors, Observing the language learner, Newark, DE: International Reading Association, 173-189.

Mitchell, R. and Myles, F. 1998: Second language learning theories. London: Arnold.

Nassaji, H. and Swain, M. (in press): A Vygotskian perspective on corrective feedback: The effect of random versus negotiated help on the learning of English articles. To appear in Language Awareness.

Newman, D., Griffin, P. and Cole, M. 1989: The construction zone: Working for cognitive change in school. Cambridge: Cambridge University Press.

Newman, F. and Holzman, L. 1993: Lev Vygotsky: Revolutionary scientist. London: Routledge. 
Perdue, C., editor, 1993: Adult second language acquisition: Cross-linguistic perspectives. Cambridge: Cambridge University Press.

Peyton, J.K. 1990: Beginning at the beginning: First-grade ESL students learning to write. In Padilla, A., Fairchild, H.H. and Valadez, C.M., editors, Bilingual education: Issues and strategies, Newbury Park, CA: Sage, 195218.

Peyton, J. K. 1993a: The development of beginning writers: Six student profiles. In Peyton, J.K. and Staton, J., editors, Dialogue journals in the multilingual classroom: Building language fluency and writing skills through written interaction, Norwood, NJ: Albex, 47-99.

Peyton, J. K. 1993b: Teacher questions in written interaction: Promoting student participation in dialogue. In Peyton, J.K. and Staton, J., editors, Dialogue journals in the multilingual classroom: Building language fluency and writing skills through written interaction, Norwood, NJ: Albex, 155-172.

Peyton, J.K. and Staton, J. editors, 1993: Dialogue journals in the multilingual classroom: Building language fluency and writing skills through written interaction, Norwood, NJ: Ablex.

Preston, D. 1996: Variationist perspectives on second language acquisition. In Bayley, R. and Preston, D., editors, Second language acquisition and linguistic variation. Amsterdam: John Benjamins, 1-45.

Sharwood Smith, M. 1994: Second language learning: Theoretical foundations. Harlow, UK: Longman.

Shuy, R. W. 1993: Using language functions to discover a teacher's implicit theory of communicating with students. In Peyton, J.K. and Staton, J., editors, Dialogue journals in the multilingual classroom: Building language fluency and writing skills through written interaction, Norwood, NJ: Albex, 127-154.

Staton, J. R., Shuy, R. W., Peyton, J.K., and Reed, L. editors, 1988: Dialogue journal communication: Classroom, linguistic, social and cognitive views. Norwood, NJ: Albex. 
Swain, M. 1997: Collaborative dialogue: Its contribution to second language learning. Revista Canaria de Estudios Ingleses 34: 115-132.

Tarone, E. 1988: Variation in interlanguage. London: Edward Arnold.

Urzua, C. 1987: "You stopped too soon": Second language children composing and revising. TESOL Quarterly 21: 279-304.

Villamil, O. and de Guerrero, M. 1996: Peer revision in the L2 classroom: Socialcognitive activities, mediating strategies, and aspects of social behavior. Journal of Second Language Writing 5: 51-75.

Vygotsky, L. S. 1978: Mind in society: The development of higher psychological processes, Cambridge, MA: Harvard University Press.

Wells, G. 1990: Talk about text: Where literacy is learned and taught. Curriculum Inquiry 20: 369-405.

Wells, G. 1998: Using L1 to master L2: A response to Antón and DiCamilla's Socio-cognitive functions of L1 collaborative interaction in the L2 classroom. Canadian Modern Language Review 53: 343-353.

Wells, G. (in press): The zone of proximal development and its implications for learning and teaching. To appear in Wells, G. (in press), Dialogic inquiry: Toward a sociocultural practice and theory of education. Http://www.oise.utoronto.ca/ gwells/zpd.discussion.txt

Wertsch, J. V. 1991: Voices of the mind: A sociocultural approach to mediated action. Cambridge, MA: Harvard University Press.

Wood, D., Bruner, J. S. and Ross, G. 1976: The role of tutoring in problemsolving. Journal of Child Psychology and Child Psychiatry 17: 89-100.

Zinchenko, V. 1985: Vygotsky's ideas about units for the analysis of mind. In Wertsch, J., editor, Culture, communication, and cognition, Cambridge: Cambridge University Press, 94-118. 
